\title{
Comparative biology of two congeneric stinkbugs, Chinavia impicticornis and C. ubica (Hemiptera: Pentatomidae)
}

\author{
Cleonor Cavalcante Alves Silva(1), Raul Alberto Laumann ${ }^{(1)}$, Maria Carolina Blassioli Moraes ${ }^{(1)}$, \\ Michely Ferreira Santos de Aquino(2) and Miguel Borges ${ }^{(1)}$
}

\begin{abstract}
(1)Embrapa Recursos Genéticos e Biotecnologia, Avenida W5 Norte (Final), CEP 70770-917 Brasília, DF, Brazil. E-mail: cleonor.silva@embrapa.br, raul.laumann@embrapa.br, carolina.blassioli@embrapa.br, miguel.borges@embrapa.br (2)Universidade de Brasília, Instituto de Biologia, Campus Universitário Darcy Ribeiro, CEP 70910-900 Brasília, DF, Brazil. E-mail: michelyf@gmail.com
\end{abstract}

Abstract-The objective of this work was to compare the biology of Chinavia impicticornis and C. ubica (Hemiptera: Pentatomidae), two species of stinkbugs that occur as secondary pests in soybean. Life table procedures were used for evaluating nymphs, and fecundity tables for evaluating adults, in order to establish the demographics of the two species. The two species have similar demographic parameters, and the development of immature stages, from egg to adult, had similar duration periods of approximately 30 days. In both species, eggs and second-instar nymphs were the stages with higher mortality. Total egg production did not differ between females of both species. Fecundity and survival curves for adults showed similar trends in both species. However, C. ubica had greater potential to increase its populations, since its fecundity parameters were significantly higher than those of C. impicticornis. Moreover, the generational time and the time required to double the population size were shorter in C. ubica. Prolonged longevity, long oviposition period, high fecundity, and the ability to rapidly increase their populations indicate that both species can become potential pests in favorable environments.

Index terms: Glycine max, age-specific fecundity, life table, mass rearing, reproductive potential, stinkbugs.

\section{Biologia comparada de dois percevejos congenéricos, Chinavia impicticornis e C. ubica (Hemiptera: Pentatomidae)}

\begin{abstract}
Resumo - O objetivo deste trabalho foi comparar a biologia de Chinavia impicticornis e de C. ubica (Hemiptera: Pentatomidae), duas espécies de percevejos que ocorrem como pragas secundárias em soja. Foram utilizados procedimentos de tabelas de vida para a avaliação de ninfas, e tabelas de fertilidade para a de adultos, no intuito de estabelecer os parâmetros demográficos das duas espécies. As duas espécies apresentam parâmetros demográficos similares, e o desenvolvimento dos estágios imaturos, de ovo a adulto, apresentou duração similar, de aproximadamente 30 dias. Nas duas espécies, ovos e ninfas do segundo instar foram os estágios com maior mortalidade. A produção total de ovos não diferiu entre as fêmeas de ambas as espécies. As curvas de fecundidade e de sobrevivência para adultos mostraram tendências semelhantes nas duas espécies. Entretanto, C. ubica apresentou maior potencial de aumentar suas populações, uma vez que seus parâmetros de fecundidade foram significativamente maiores do que os de C. impicticornis. Além disso, o tempo generacional e o tempo necessário para dobrar a população em tamanho foram mais curtos em C. ubica. A longevidade prolongada, o longo período de oviposição, a alta fertilidade e a capacidade de aumentar rapidamente suas populações indicam que ambas as espécies podem tornar-se pragas potenciais, em ambientes favoráveis.
\end{abstract}

Termos para indexação: Glycine max, fecundidade por idade, tabela de vida, criação em massa, potencial reprodutivo, percevejos.

\section{Introduction}

Chinavia impicticornis (Stål, 1872) and Chinavia ubica (Rolston, 1983) (Hemiptera: Pentatomidae) are sympatric species of pentatomids known as green stinkbugs. They have been reported as minor components of the stinkbug pest complex, which is economically important in many crops, mainly Solanaceae and Leguminosae (Panizzi et al., 2000). These species were formerly considered to belong to the genus Acrosternum Fieber, 1860, but the taxonomic position of some Afrotropical species and of all Nearctic and Neotropical species was reviewed, which reorganized the subgenus Chinavia as a valid genus (Schwertner \& Grazia, 2006). 
In Brazil, 32 Chinavia species have been recorded, from which 18 are considered potential pests, exploiting a large number of plant families (Panizzi et al., 2000; Schwertner \& Grazia, 2006, 2007; Panizzi, 2007). Chinavia impicticornis and C. ubica have wide geographical distribution, being found in all Brazilian regions (Schwertner \& Grazia, 2007). In crops, both species are recorded mainly in soybean (Panizzi et al., 2000). Although they have not yet been reported as major pests, C. impicticornis and C. ubica may become increasingly destructive secondary pests, since they are found feeding and ovipositing in several important crops (Panizzi et al., 2000; Panizzi, 2007).

In Central Brazil, populations of stinkbugs should be evaluated in monitoring programs in order to avoid an epidemic growth that may result in economic damage to soybean crops (Corrêa-Ferreira \& Azevedo, 2002). In addition to direct feeding damage, stinkbugs are known to facilitate infection by plant pathogens such as bacteria and yeast (Daugherty, 1967; Clarke \& Wilde, 1970).

The morphology of the immature stages and some biological aspects of these two Chinavia species have already been reported (Grazia et al., 1982, Schwertner et al., 2002), and a preliminary laboratory study showed that C. impicticornis and C. ubica have similar development time, high fecundity (Laumann et al., 2006), and an efficient intraspecific communication during the reproductive stage, by means of chemical and vibratory signals (Moraes et al., 2005, 2008).

The reasons and the means by which insect populations increase are central questions in basic and applied ecology (Laughlin, 1965; Royama, 1981; Peterson et al., 2009). Life table studies from laboratory data can help answering these questions (Royama, 1981). Life table studies give basic information on survivorship, development, and reproduction rate of insect species, and can reveal their most vulnerable stage under specified conditions. These information help identifying specific events, such as death of immatures and reproductive rates, which can be used to improve rearing techniques. Moreover, they provide population growth indicators that could help establishing control strategies (Southwood, 2000; Yu et al., 2005; Polanco et al., 2011). For example, short developmental time together with high fecundity and longevity, on a given host plant, usually indicate greater suitability of the host to support infestation and increasing population of the species (Southwood, 2000).

The objective of this work was to compare the biology of C. impicticornis and C. ubica, two species that occur as secondary pests in soybean.

\section{Materials and Methods}

Adults of C. impicticornis and C. ubica came from colonies maintained for five generations in the Semiochemical Laboratory of Embrapa Recursos Genéticos e Biotecnologia, located in Brasília, Distrito Federal, Brazil; and voucher specimen were deposited in the institution's insect collection. The insects were reared in 8-L transparent plastic containers, and fed a standard diet composed of green bean pods (Phaseolus vulgaris L.), dry soybean seeds (Glycine max L.), raw peanuts (Arachis hypogaea L.), sunflower seeds (Helianthus annuus L.), and water. A $15-\mathrm{cm}^{2}$ plastic mesh ( $\sim 0$ meshes) was placed against the inner wall of each container to serve as oviposition substrate and shelter for the bugs. The containers were covered with voile and kept at $26 \pm 1^{\circ} \mathrm{C}$ and at $65 \pm 10 \%$ relative humidity.

In order to build a stage-specific life table, egg masses from each species (78 egg masses with 993 eggs for C. impicticornis, and 73 egg masses with 1,945 eggs for $C$. ubica) were collected from the colony, placed in Petri dishes ( $9 \mathrm{~cm}$ in diameter $\mathrm{x} 2 \mathrm{~cm}$ in height) at the density of 100 eggs per dish, and inspected daily for egg hatching, survival, and development progress, from first to second instar. As food supply and source of humidity, a green bean pod was offered inside the Petri dishes. After the second instar was reached, nymphs of $C$. impicticornis $(\mathrm{n}=248)$ and $C$. ubica $(\mathrm{n}=470)$ were transferred to the 8 - $\mathrm{L}$ transparent plastic containers in groups of $\sim 100$ nymphs per container, which represented the jointed nymphs from 2 to 5 Petri dishes, in order to complete their development. The food source was the standard diet described before. Development time (time when half +1 of the nymphs from each group molt into the following instar) and survival rate $\left(l_{x}=\right.$ proportion of individuals alive in each instar, calculated as the proportion from the initial number of individuals, i.e. eggs) of each immature stage were calculated for each species. Survivorship curves were drawn from egg to adult stage. 
Males and females - emerged on the same day from the nymphs reared in the above conditions were paired ( 1 female and 1 male) and transferred to 250-mL capacity oviposition cages, with the same food substrate previously described. A total of 50 couples of C. impicticornis and 45 couples of C. ubica were observed daily, and sexual maturity, age at first oviposition, oviposition period, and longevity were recorded. The number of egg masses, the number of eggs per mass, and the total lifetime fecundity (total eggs per female) were also quantified. Age-specific fecundity $\left(\mathrm{m}_{\mathrm{x}}=\right.$ mean number of females per female per day) was estimated for each species, as the product between the mean number of eggs per female per day, the mean immature survivorship (from the estimation of immature survivorship), and the female rate $(0,5)$, considering the typical sex rate of the species (1:1, female: male).

Curves of the immature stages of each species were compared with the Kaplan-Meier (1958) survival analysis and log-rank test. The development time of each immature stage and the total developmental time of each species were compared by generalized linear models (GLMs) and deviance analyses, using models with inverse Gaussian error distribution and the $\mathrm{F}$ test. The same procedures were used to compare the longevity of males and females between species. The total number of egg masses per female and the total number of eggs per female were compared between species by the GLM and deviance analyses, using models with Poisson and quasi-Poisson error distribution, respectively, and the $\chi^{2}$ test. The number of eggs per egg mass was compared between species with a GLM, using species as fixed factor and individual as a random factor, as well as Poisson distribution of errors for the models.

Data from female age $(\mathrm{x}=$ computed as days in adult life + mean development time of immature stages), survivorship $\left(1_{x}\right)$, and specific fecundity $\left(\mathrm{m}_{\mathrm{x}}\right)$ were used to estimate the mean and standard deviation of fecundity table parameters using the Life Table computer program (Maia et al., 2000), with functions and procedures embedded on the SAS System for Windows (SAS Institute, Cary, NC, USA). This program uses the jackknife technique to estimate life table parameters (Meyer et al., 1986). The estimated parameters, following the definitions of Birch (1948) and Southwood (2000), were: net reproductive rate $\left(\right.$ Ro $\left.=\sum 1_{x} m_{x}\right)$, which represents the number of females per female per generation; intrinsic rate of increase $\left(\mathrm{r}_{\mathrm{m}}=\ln \mathrm{Ro} / \mathrm{T}\right)$, which expresses the instantaneous production of females per female; daily finite rate of increase $\left(\lambda=r_{m}\right.$, in females per female per day); mean generation time $\left(\mathrm{T}=\Sigma \mathrm{m}_{\mathrm{x}} \mathrm{l}_{\mathrm{x}} \mathrm{x} / \mathrm{Ro}\right)$; and time to double population in size $\left(\mathrm{DT}=\operatorname{In}(2) / \mathrm{r}_{\mathrm{m}}\right)$.

Life Table parameters estimated for each species were compared by $t$ tests, using the mean from the jackknife estimates of their respective variances. All statistical tests were performed at $5 \%$ probability.

\section{Results and Discussion}

The total development time from egg hatching to adult emergency did not differ between $C$. impicticornis and C. ubica (Table 1). Chinavia impicticornis took less time to complete its initial development stages (eggs and first- and second-instar nymphs) than C. ubica; however, the time length required to complete the third and the fourth nymphal stages was higher in the former species, and the development time of the fifth nymphal stage did not show statistical differences between species.

Similar egg development time was reported for other Chinavia species: 6.8 days for $C$. marginatum Palisot de Beauvois, 1817; 8 days for C. apicicornis Spinola, 1852; 6 days for $C$. bella Rolston, 1983; 6.7 days for C. longicorialis Breddin, 1901; 8.4 days for C. obstinata Stål, 1860; and 8 days for C. pengue Rolston, 1983 (La Porta \& Avalos, 1993; Avalos \& La Porta, 1996; Matesco et al., 2007, 2009). However, the development time from egg to adult registered for these species was longer than those obtained for C. impicticornis and C. ubica: 42 days for $C$. marginatum; 45.3 days for $C$. apicicornis; 38.5 days for $C$. bella; 86 days for $C$. obstinate; 45.7 days for $C$. pengue; and 39 days for $C$. longicorialis (Hallman et al., 1992; La Porta \& Avalos, 1993; Avalos \& La Porta, 1996; Matesco et al., 2003, 2007, 2009). Besides physiological particularities of each species, the differences observed between them may also be due to: food sources, time (number of generations) in laboratory rearing, environmental conditions, or rearing procedures.

The survival curves for the immature stages showed similar patterns for both species (Figure 1), but differed statistically through comparative analysis 
of the curves by the Kaplan-Meier survival analysis and log-rank test $(\mathrm{S}=7.43, \mathrm{df}=1, \mathrm{p}=0.006)$. From the original cohort of $C$. impicticornis ( $\mathrm{n}=993 \mathrm{eggs})$, the mortality rate was highest in the egg stage (37.6\%), followed by second-instar nymphs $(47.4 \%)$; whereas in C. ubica (starting with $\mathrm{n}=1,945$ eggs), the mortality was $42.80 \%$ for eggs and $34.2 \%$ for fourth-instar nymphs. Since the insects were reared under controlled conditions, where many environmental mortality factors present in the field - such as temperature variations, precipitations, and presence of competitors or predators - are absent, the mortality observed may be due to natural intrinsic mortality. However, even in this case, rearing conditions cannot be disregarded. In general, diet composition and environmental conditions influence insect performance (Parra, 2001; Cohen, 2004; Parra et al., 2012), particularly for the Pentatomidae family (Panizzi, 1997; Silva et al., 2008; Silva et al., 2011), in laboratory colonies. Since the optimal rearing conditions are not know for C. ubica and $C$. impicticornis, a negative influence of the procedures and environmental conditions adopted in the present work could still have had a significant influence on their development.

Therefore, for C. ubica and C. impicticornis mass rearing purposes, nymphal mortality should be properly addressed and minimized. According to Nath \& Rai (2010), reduced survival in early stages, with mortality prior to sexual maturity, plays a key role in decreasing the population size. Matesco et al. (2009) observed high mortality ( $82 \%$ ) of $C$. longicornis from first- to fifth-instar nymphs, which made it impossible to keep the insects in the laboratory up to the second generation. Moreover, females of this species did not display copulatory behavior and egg-laying activity. The authors suggest a clear influence of the diet on the mortality of immature stages of $C$. longicornis because egg and first-instar nymph showed lower mortality (Matesco et al., 2009). Wild hosts, besides some other cultivated plants, are fundamental for immature and adult performance of stinkbugs (Panizzi, 1997). Therefore, one alternative for reducing the mortality of immature instars of C. ubica and C. impicticornis could be the incorporation of some wild plants in their diets.

The species differed as to mean adult longevity of males and females. Chinavia impicticornis had higher longevity, with its males living $31.5 \%$ more than C. ubica males, and its females living 38\% more than C. ubica females (Table 1). As C. impicticornis and C. ubica were reared under the same diet and environmental conditions, the differences observed in adult longevity could represent natural differences between the species or a better adaptation of $C$. impicticornis adults to laboratory conditions. Maximal life span of females differed between both species: 121 days for C. impicticornis and 80 days for C. ubica (Figure 2). Mean adult longevity of C. impicticornis (78.0 \pm 29.8 days for males and $66.8 \pm 26.3$ days for females) and C. ubica (53.4 \pm 35.4 days for males and $41.4 \pm 29.1$ days for females) was similar to the ones reported for other pentatomid species under the same diet and laboratory

Table 1. Development time of immature stages, male and female longevity, and female fecundity of Chinavia impicticornis and Chinavia ubica fed on green bean pods, dry soybean seeds, raw peanuts, and sunflower seeds, at $26 \pm 1{ }^{\circ} \mathrm{C}$, $65 \pm 10 \%$ relative humidity, and photoperiod of 14:10 hours light:dark.

\begin{tabular}{|c|c|c|c|}
\hline Parameter & Chinavia impicticornis & Chinavia ubica & Test \\
\hline & \multicolumn{3}{|c|}{ Development time (days) } \\
\hline Egg & $5.2 \pm 1.5$ & $5.7 \pm 0.9$ & $\mathrm{~F}_{1,1304}=42.79 ; \mathrm{p}<0.001$ \\
\hline $1^{\text {st }}$ instar & $4.2 \pm 1.2$ & $4.6 \pm 1.3$ & $\mathrm{~F}_{1,971}=34.42 ; \mathrm{p}<0.001$ \\
\hline $2^{\text {nd }}$ instar & $4.3 \pm 1.4$ & $4.9 \pm 1.6$ & $\mathrm{~F}_{1,719}=39.88 ; \mathrm{p}<0.001$ \\
\hline $3^{\text {rd }}$ instar & $4.6 \pm 1.7$ & $4.1 \pm 1.3$ & $\mathrm{~F}_{1,564}=15.88 ; \mathrm{p}<0.001$ \\
\hline $4^{\text {th }}$ instar & $5.0 \pm 2.1$ & $4.4 \pm 1.4$ & $\mathrm{~F}_{1,418}=6.71 ; \mathrm{p}<0.01$ \\
\hline $5^{\text {th }}$ instar & $8.2 \pm 2.3$ & $7.9 \pm 1.8$ & $\mathrm{~F}_{1,326}=2.27 ; \mathrm{p}=0.13$ \\
\hline \multirow[t]{2}{*}{ Egg-adult } & $30.5 \pm 4.8$ & $30.3 \pm 3.6$ & $\mathrm{~F}_{1,222}=0.10 ; \mathrm{p}=0.75$ \\
\hline & \multicolumn{3}{|c|}{ Adult longevity (days) } \\
\hline Male & $78.0 \pm 29.8$ & $53.4 \pm 35.4$ & $\mathrm{~F}_{1,91}=10.33 ; \mathrm{p}<0.01$ \\
\hline Female & $66.8 \pm 26.3$ & $41.4 \pm 29.1$ & $\mathrm{~F}_{1,93}=14.65 ; \mathrm{p}<0.001$ \\
\hline Total fecundity (eggs per female) & $198.7 \pm 112.2$ & $159.1 \pm 160.9$ & $\chi_{1,94}^{2}=52,25 ; p=0.17$ \\
\hline
\end{tabular}


conditions, such as Euschistus heros (46.5 \pm 19.7 days for males and 52.2 \pm 19.7 days for females) (Costa et al., 1998) and Edessa meditabunda (63.3 \pm 8.0 days for males and 60.5 \pm 9.9 days for females) (Silva et al., 2012).

Mated females of $C$. impicticornis started laying eggs at the age of $9.8 \pm 2$ days from the final molt, and over the course of their lifetime an average of 13.5 \pm 7.3 egg masses were laid. Mated females of $C$. ubica started ovipositing at the age of $10.3 \pm 1.8$ days, and laid an average of $6.07 \pm 5.5$ egg masses, significantly lower than that of $C$. impicticornis $\left(\chi_{1,94}^{2}=3,30 ; p<0.001\right)$. The period required to reach sexual maturity, between the final molt and the first copula, for both species, was shorter than those reported for other Chinavia species, which took between 12.4 to 13.8 days (La Porta \& Avalos, 1993; Avalos \& La Porta, 1996). Chinavia impicticornis laid egg masses with significant lower number of eggs $(14.3 \pm 1.7)$ than C. ubica $(23.4 \pm 7.0)$ $(G L M z=9.95 ; p<0.001)$. Despite the differences in the number of eggs per egg mass, total egg production per female between species did not show statistical differences (Table 1), because the lower number of egg masses in C. ubica is offset by a higher number of eggs

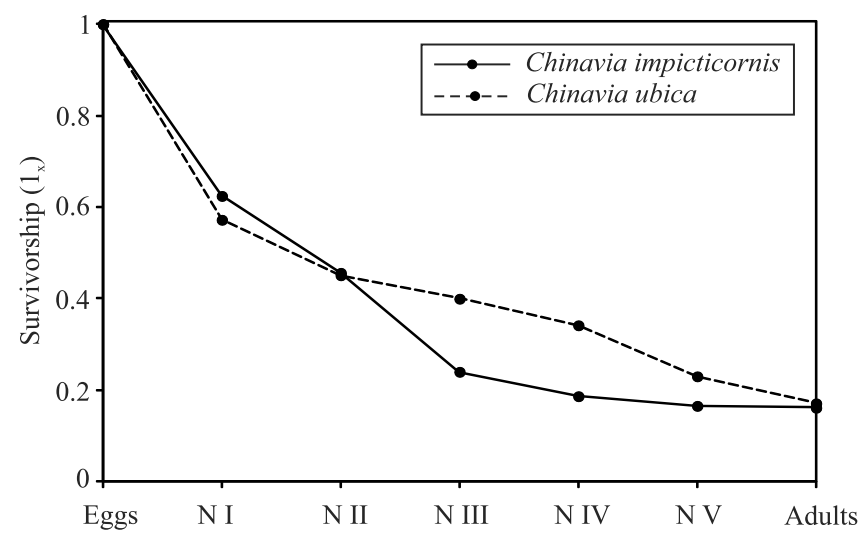

Figure 1. Age-specific survivorship of immature stages of Chinavia impicticornis and C. ubica, fed on green bean pods, dry soybean seeds, raw peanuts, and sunflower seeds at $26 \pm 1^{\circ} \mathrm{C}, 80 \pm 10 \%$ relative humidity, and photoperiod of 14:10 hours light:dark. $l_{x}$ is the survivorship, calculated as the proportion from the initial number of individuals, i.e. eggs, in this case $\mathrm{n}=993$ for $C$. impicticornis and $\mathrm{n}=1,945$ for $C$. ubica. N I to N V refer to first- to fifth-instar nymphs, respectively. per egg mass. Other species of Chinavia (C. obstinata, $C$. pengue, and $C$. longicorialis) showed similar fecundity values (Matesco et al., 2003, 2007, 2008) to those reported here.

Fecundity and survival curves for adults of both species showed similar trends (Figure 2). Female mortality showed lower rates in $C$. impicticornis than in C. ubica. Fecundity rate $\left(\mathrm{m}_{\mathrm{x}}\right)$ peaks showed similar
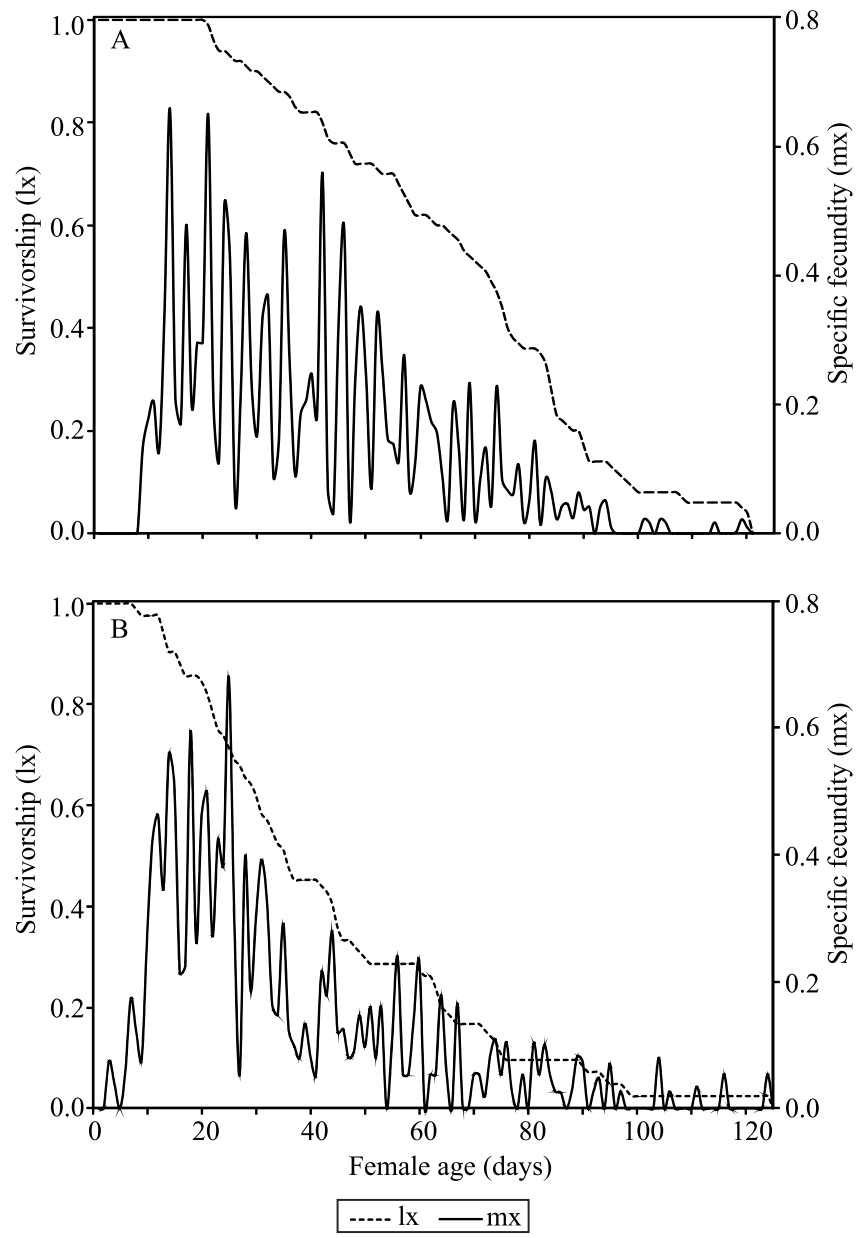

Figure 2. Age-specific survivorship and fecundity of Chinavia impicticornis (A) and C. ubica (B) females fed on green bean pods, dry soybean seeds, raw peanuts, and sunflower seeds, at $26 \pm 1^{\circ} \mathrm{C}, 65 \pm 10 \%$ relative humidity, and photoperiod of 14:10 hours light:dark. $1_{x}$ is the survivorship, calculated as the proportion from the initial number of individuals, i.e. eggs, in this case $n=50$; and $m_{x}$ is the age-specific fecundity, determined as the mean number of females per female per day.

Pesq. agropec. bras., Brasília, v.50, n.5, p.355-362, maio 2015 DOI: $10.1590 / \mathrm{S} 0100-204 \mathrm{X} 2015000500002$ 
values in both species, but in C. ubica, peaks were maintained with a lower number of oscillations and concentrated in a shorter period of time.

The net reproduction rate (Ro) did not differ significantly between species (Table 2), and both of them were able to increase in number, which reveals that laboratory conditions and food were adequate for rearing. However, the following parameters of fecundity tables differed significantly between species: intrinsic rate of natural increase $\left(r_{m}\right)$, finite rate of increase $(\lambda)$, generation time $(T)$, and doubling time (DT). According to these results, C. ubica had a higher capacity to increase its population in a shorter time, compared to $C$. impicticornis. The similarity in survivorship of immature stages and in fecundity of females of both species probably influenced this result, but $C$. ubica had progeny production centered in a shorter time (Figure 2). Therefore, if the species preserves this behavior in field conditions, C. ubica would have a higher capacity to increase its population in a shorter time and at higher rates than C. impicticornis.

The biologic potential of both species (i.e., the number of offspring produced in the subsequent generation) is comparable to the ones observed in other pentatomid species, such as the brown stinkbug, $E$. heros, reared under the same laboratory conditions (Silva et al., 2008).

The results obtained in the present study indicate that both Chinavia species evaluated should be included in monitoring programs of stinkbugs in crops such as soybean and common beans.

Table 2. Mean \pm standard deviation of fecundity life table parameters of Chinavia impicticornis and C. ubica fed on green bean pods, dry soybean seeds, raw peanuts, and sunflower seeds, at $26 \pm 1^{\circ} \mathrm{C}, 80 \pm 10 \%$ relative humidity, and photoperiod of 14:10 hours light:dark.

\begin{tabular}{lccc}
\hline Parameter & $\begin{array}{c}\text { Chinavia } \\
\text { impicticornis }\end{array}$ & $\begin{array}{c}\text { Chinavia } \\
\text { ubica }\end{array}$ & $\begin{array}{c}\mathrm{p} \\
\text { value }\end{array}$ \\
\hline Net reproduction rate & $15.9 \pm 1.3$ & $13.6 \pm 2.1$ & 0.33 \\
Mean generation time (days) & $59.6 \pm 1.4$ & $48.1 \pm 1.9$ & 0.001 \\
Intrinsic rate of increase & $0.04 \pm 0.001$ & $0.05 \pm 0.003$ & 0.02 \\
Time to double in size (days) & $14.9 \pm 0.3$ & $12.7 \pm 0.7$ & 0.009 \\
Finite rate of increase & $1.05 \pm 0.001$ & $1.06 \pm 0.003$ & 0.02 \\
\hline
\end{tabular}

\section{Conclusions}

1. The two congeneric species of stinkbugs, Chinavia impicticornis and C. ubica, have similar biological traits under laboratory conditions.

2. Prolonged longevity, long oviposition period, high fecundity, and the ability to rapidly increase their populations indicate that these species can become potential crop pests in favorable environments (climate and access to food).

3. Both species can be mass reared successfully under laboratory conditions.

4. Eggs and second-instar nymphs are the most susceptible and the key stages to focus on when thinking in mass rearing.

\section{Acknowledgments}

To International Foundation for Science (IFS), to Conselho Nacional de Desenvolvimento Científico e Tecnológico (CNPq), and to Fundação de Amparo à Pesquisa do Distrito Federal (FAPDF), for financial support; and to Dr. Jocelia Grazia from Universidade Federal do Rio Grande do Sul (UFRGS) and to Dr. Cristiano Feldens Schwertner from Universidade Federal de São Paulo (Unifesp), for their help on the identification of the insects.

\section{References}

AVALOS, D.S.; LA PORTA, N.C. Biología de Acrosternum bellum Rolston, 1983 (Hemiptera: Pentatomidae). Agriscientia, v.13, p.25-30, 1996.

BIRCH, L.C. The intrinsic rate of natural increase of an insect population. Journal of Animal Ecology, v.17, p.15-26, 1948. DOI: $10.2307 / 1605$.

CLARKE, R.G.; WILDE, G.E. Association of the green stink bug and the yeast-spot disease organism of soybeans. I. Length of retention, effect of molting, isolation from feces and saliva. Journal of Economic Entomology, v.63, p.200-204, 1970. DOI: 10.1093/jee/63.1.200.

COHEN, A.C. Insects diets: science and technology. Boca Ratón: CRC Press, 2004.

CORRÊA-FERREIRA, B.S.; AZEVEDO, J. de. Soybean seed damage by different species of stink bugs. Agricultural Forest Entomology, v.4, p.145-150, 2002. DOI: 10.1046/j.1461-9563.2 002.00136.x.

COSTA, M.L.M.; BORGES, M.; VILELA, E.F. Biologia reprodutiva de Euschistus heros (F.) (Heteroptera: Pentatomidae). Anais da Sociedade Entomológica do Brasil, v.27, p.559-568, 1998. DOI: 10.1590/S0301-80591998000400008. 
DAUGHERTY, D.M. Pentatomidae as vectors of yeast-spot disease of soybeans. Journal of Economic Entomology, v.60, p.147-152, 1967. DOI: $10.1093 /$ jee/60.1.147.

GRAZIA, J.; DEL VECCHIO, M.C.; HILDEBRAND, R. Estudo das ninfas de pentatomídeos (Heteroptera) que vivem sobre soja [Glycine max (L.) Merrill]: IV - Acrosternum impicticorne (Stal, 1872). Anais da Sociedade Entomológica do Brasil, v.11, p.261-268, 1982.

HALLMAN, G.J.; MORALES, C.G.; DUQUE, M.C. Biology of Acrosternum marginatum (Heteroptera: Pentatomidae) on common beans. Florida Entomologist, v.75, p.190-196, 1992.

KAPLAN, E.L.; MEIER, P. Nonparametric estimation from incomplete observations. Journal of the American Statistical Association, v.53, p.457-481, 1958. DOI: 10.1080/01621459.1958.10501452.

LA PORTA, N.C.; AVALOS, D.S. Aspectos biológicos de Acrosternum apicicorne (Spinola, 1862) (Hemiptera, Pentatomidae). Agriscientia, v.10, p.45-49, 1993.

LAUGHLIN, R. Capacity for increase: a useful population statistic. Journal of Animal Ecology, v.34, p.77-91, 1965. DOI: $10.2307 / 2370$.

LAUMANN, R.A.; AQUINO, M.F.S.; MOTTA, L.S.M.; SANTOS, H.M.; MORAES, M.C.B.; BORGES, M. Parâmetros biológicos de populações de Chinavia ubica e Chinavia impicticornis (Hemíptera: Pentatomidae) do Distrito Federal. Brasília: Embrapa Recursos Genéticos e Biotecnologia, 2006. (Comunicado técnico, 150).

MAIA, A. de H.N.; LUIZ, A.J.B.; CAMPANHOLA, C. Statistical inference on associated fertility life table parameters using jackknife technique: computational aspects. Journal of Economic Entomology, v.93, p.511-518, 2000. DOI: 10.1603/0022-0493-93.2.511.

MATESCO, V.C.; SCHWERTNER, C.F.; GRAZIA, J. Descrição dos estágios imaturos e biologia de Chinavia pengue (Rolston) (Hemiptera, Pentatomidae). Revista Brasileira de Entomologia, v.51, p.93-100, 2007. DOI: 10.1590/S0085-56262007000100016.

MATESCO, V.C.; SCHWERTNER, C.F.; GRAZIA, J. Imaturos de pentatomídeos (Hemiptera, Heteroptera): morfologia e biologia de Acrosternum obstinatum. Iheringia. Série Zoologia, v.93, p.81-88, 2003. DOI: $10.1590 /$ S0073-47212003000100009.

MATESCO, V.C.; SCHWERTNER, C.F.; GRAZIA, J. Immature stages of Chinavia musiva (Berg, 1878): a unique pattern in the morphology of Chinavia Orian, 1965 (Hemiptera, Pentatomidae). Journal of Natural History, v.42, p.1749-1763, 2008. DOI: $10.1080 / 00222930802124297$.

MATESCO, V.C.; SCHWERTNER C.F.; GRAZIA, J. Morphology of the immatures and biology of Chinavia longicorialis (Breddin) (Hemiptera: Pentatomidae). Neotropical Entomology, v.38, p.74-82, 2009. DOI: 10.1590/S1519-566X2009000100007.

MEYER, J.S.; INGERSOLL, C.G.; MCDONALD, L.L.; BOYCE, M.S. Estimating uncertainty in population growth rates: jackknife vs. bootstrap techniques. Ecology, v.67, p.1156-1166, 1986. DOI: $10.2307 / 1938671$.
MORAES, M.C.B.; LAUMANN, R.A.; COKL, A.; BORGES, M. Vibratory signals of four Neotropical stink bug species. Physiological Entomology, v.30, p.175-188, 2005. DOI: 10.1111/j. 1365-3032.2005.00446.x.

MORAES, M.C.B.; PAREJA, M.; LAUMANN, R.A.; BORGES, M. The chemical volatiles (semiochemicals) produced by neotropical stink bugs (Hemiptera: Pentatomidae). Neotropical Entomology, v.37, p.489-505, 2008. DOI: 10.1590/S1519-566X2008000500001.

NATH, S.; RAI, A. Study of life table of Ceracris nigricornis laeta (Orthoptera: Acrididae) in laboratory conditions. Romanian Journal of Biology - Zoology, v.55, p.159-165, 2010.

PANIZZI, A.R. Nutritional ecology of plant feeding arthropods and IPM. In: KOGAN, M.; JEPSON, P. (Ed.). Perspectives in ecological theory and integrated pest management. New York: Cambridge University Press, 2007. p.170-222. DOI: 10.1017/ CBO9780511752353.007.

PANIZZI, A.R. Wild hosts of pentatomids: ecological significance and role in their pest status on crops. Annual Review of Entomology, v.42, p.99-122, 1997.

PANIZZI, A.R.; MCPHERSON, J.E.; JAMES, D.G.; JAVAHERY, M.; MCPHERSON, R.M. Stink bugs (Pentatomidae). In: SCHAEFER, C.W.; PANIZZI, A.R. (Ed.). Heteroptera of economic importance. Boca Ratón: CRC Press, 2000. p.421-474.

PARRA, J.R.P. Técnicas de criação de insetos para programas de controle biológico. 6.ed. Piracicaba: Fundação de Estudos Agrários Luiz Queiroz, 2001. 134p.

PARRA, J.R.P.; PANIZZI, A.R.; HADDAD, M.L. Nutritional indices for measuring insect food intake and utilization. In: PANIZZI, A.R.; PARRA, J.R.P. (Ed.). Insect bioecology and nutrition for integrated pest management. Boca Ratón: CRC Press, 2012. p.13-49.

PETERSON, R.K.D.; DAVIS, R.S.; HIGLEY, L.G.; FERNANDES, O.A. Mortality risk in insects. Environmental Entomology, v.38, p.2-10, 2009. DOI: 10.1603/022.038.0102.

POLANCO, A.M.; BREWSTER, C.C.; MILLER, D.M. Population growth potential of the bed bug, Cimex lectularius L.: a life table analysis. Insects, v.2, p.173-185, 2011. DOI: 10.3390/ insects2020173.

ROYAMA, T. Evaluation of mortality factors in insect life table analysis. Ecological Monographs, v.51, p.495-505, 1981. DOI: $10.2307 / 2937326$.

SCHWERTNER, C.F.; ALBUQUERQUE, G.S.; GRAZIA, J. Descrição dos estágios imaturos de Acrosternum (Chinavia) ubicum Rolston (Heteroptera: Pentatomidae) e efeito do alimento no tamanho e coloração das ninfas. Neotropical Entomology, v.31, p.571-579, 2002. DOI: 10.1590/S1519-566X2002000400009.

SCHWERTNER, C.F.; GRAZIA, J. Descrição de seis espécies de Chinavia (Hemiptera, Pentatomidae, Pentatominae) da América do Sul. Iheringia. Série Zoologia, v.96, p.237-248, 2006. DOI: 10.1590/S0073-47212006000200015.

SCHWERTNER, C.F.; GRAZIA, J. O gênero Chinavia Orian (Hemiptera, Pentatomidae, Pentatominae) no Brasil, com chave pictórica para os adultos. Revista Brasileira de Entomologia, v.51, p.416-435, 2007. DOI: 10.1590/S0085-56262007000400005. 
SILVA, C.C.; LAUMANN, R.A.; BLASSIOLI, M.C.; PAREJA, M.; BORGES, M. Euschistus heros mass rearing technique for the multiplication of Telenomus podisi. Pesquisa Agropecuária Brasileira, v.43, p.575-580, 2008. DOI: 10.1590/ S0100-204X2008000500004.

SILVA, C.C.A.; LAUMANN, R.A.; FERREIRA, J.B.C.; MORAES, M.C.B.; BORGES, M.; ČOKL, A. Reproductive biology, mating behavior, and vibratory communication of the brown-winged stink bug, Edessa meditabunda (Fabr.) (Heteroptera: Pentatomidae). Psyche, article ID 598086, 2012. DOI:10.1155/2012/598086.

SILVA, F.A.C.; CALIZOTTI, G.S.; PANIZZI, A.R. Survivorship and egg production of phytophagous pentatomids in laboratory rearing. Neotropical Entomology, v.40, p.35-38, 2011. DOI: 10.1590/S1519-566X2011000100005.

SOUTHWOOD, T.R.E. The construction, description and analysis of age-specific life tables. In: SOUTHWOOD, T.R.E.; HENDERSON, P.A. (Ed.). Ecological methods. $3^{\text {rd }}$ ed. Oxford: Blackwell Science, 2000. p.404-436. DOI: 10.1007/978-94-009-1225-0.

YU, J.-Z.; CHI, H.; CHEN, B.-H. Life table and predation of Lemnia biplagiata (Coleoptera: Coccinellidae) fed on Aphis gossypii (Homoptera: Aphididae) with a proof on relationship among gross reproduction rate, net reproduction rate, and preadult survivorship. Annals of the Entomological Society of America, v.98, p.475-482, 2005. DOI: 10.1603/0013-8746(2005)098[0475:LTAP OL]2.0.CO;2.

Received on May 30, 2014 and accepted on March 31, 2015 